\title{
A ORIENTAÇÃO DAS DISSERTAÇÕES E TESES COMO OBJETO DE ESTUDO DAS PESQUISAS ACADÊMICAS: HISTÓRIA E HISTORIOGRAFIA
}

\author{
Paulo Sérgio de Almeida Corrêa ${ }^{1}$ \\ Universidade Federal do Pará - UFPA
}

\section{RESUMO}

Analiso as representações discursivas que circulam nas produções acadêmicas dos autores cujos trabalhos teóricos elegem a pós-graduação e o processo de orientação das dissertações e teses como campo investigativo. De que forma a temática orientação é tratada teórico-metodologicamente como objeto de estudo na produção científica dos pesquisadores brasileiros? Constitui pesquisa bibliográfica sobre quatro tipos de veículos de circulação da produção científica: ANPEd (GT-11); Revista Brasileira de Educação; Livros Publicados; e textos extraídos de Outras Fontes. Os Programas de Pós-Graduação precisam atribuir maior visibilidade ao processo de orientação das dissertações e teses, pois esse momento pedagógico tem merecido pouca atenção institucional, como também escapa das opções temáticas investigativas de grande parte dos pesquisadores brasileiros.

Palavras-chave: Pós-Graduação; Processo de Orientação; Historiografia Educacional

\section{ORIENTATION OF DISSERTATION AND THESIS AS AN OBJECT OF STUDY OF ACADEMIC RESEARCH: HISTORY AND HISTORIOGRAPHY}

\begin{abstract}
I analyze the discursive representations circulating in academic productions of authors whose theoretical work to elect postgraduate and orientation process of dissertations and theses as a Field investigation. How the thematic orientation is theoretically and methodologically treated as an object of study in the scientific production of Brazilian research? Literature is on four types of vehicles circulation of scientific production: ANPED (GT-11); Journal of Education; Published Books; and text extracted from Other Fonts. The Postgraduate Programs need give greater visibility to the process orientation of dissertations and theses, because this time teaching institution has received little attention, but also escapes the investigative thematic option of most Brazilian researchers.

Keywords: Postgraduate; Process Orientation; Educational Historiography.
\end{abstract}

\section{Introdução}

O escopo deste trabalho consistiu na análise das representações discursivas que circulam nas produções acadêmicas dos autores cujos trabalhos teóricos elegem a pós-graduação e o processo de orientação das dissertações e teses como campo investigativo. A intenção foi compreender como os pesquisadores se apropriam do assunto para articular suas narrativas históricas em torno desse objeto. Para tanto, formulei análises em torno da seguinte arguiição: De que forma a temática orientação é tratada teórico-metodologicamente como objeto de estudo na produção científica dos pesquisadores brasileiros?

Enquanto procedimento metodológico adotou-se como referência a pesquisa bibliográfica com incidência sobre quatro tipos de veículos de circulação da produção científica, a saber: Reunião Anual da Associação Nacional de Pesquisa e Pós-Graduação em Educação ANPEd, particularmente os textos apresentados no Grupo de Trabalho Política de 
Educação Superior (GT-11); Revista Brasileira de Educação - RBE; Livros Publicados sobre o tema; e textos extraídos de Outras Fontes, tais como: sítios na internet e Periódicos. O estudo dos trabalhos catalogados incidiu sobre o Ano de Publicação, a Instituição de Ensino Superior a que se vincula o autor, a Autoria, temática expressa nos Títulos, as Finalidades das Pesquisas, Questões Investigativas propostas, Metodologia Empregada, Fontes Históricas utilizadas, Período Histórico abrangido pelos estudos e Resultados atingidos.

Para o desenvolvimento da pesquisa elegi 31 (trinta e um) trabalhos, dentre os quais 5 (cinco) foram acessados no GT-11 da ANPEd (16,12\%); 7 (sete) tiveram sua origem na RBE, representando 22,58\%; outros 6 (seis) tiveram sua extração de Outras Fontes 19,35\%; e 13 (treze) são procedentes de Capítulos de Livros, exibindo a média estatística de $41,93 \%$.

\section{A incidência dos trabalhos segundo a dimensão Ano de Publicação}

Convém destacar que o lapso histórico coberto pelos textos, no que concerne ao ano de suas respectivas publicações, teve no período de 1996 a 2008 sua principal incidência temporal, o que revela, de início, o absenteísmo dos pesquisadores em relação a um tema tão essencial na vida dos Programas de Pós-Graduação.

Observando-se o quantitativo dos textos consultados, ficou evidente que a temática relacionada à pós-graduação e à orientação gozava de pouco prestígio na agenda investigativa dos pesquisadores brasileiros. Somente no ano de 1996 veio a público o primeiro trabalho no âmbito institucional da ANPEd, representando 3,22\% do total da amostra analisada. A mesma incidência se verificou no ano 2000, porém a origem era de Outras Fontes (Revista Diálogo Educacional).

No ano de 2001, apenas dois textos foram publicados, sendo um emanado do GT-11 da ANPEd e um da RBE, ficando com o porcentual de 6,45\% em relação ao quantitativo geral, não tendo havido manifestação em Outras Fontes e tampouco em Capítulos de Livros.

Momento de maior efervescência nas publicações coincidiu com o ano de 2002, quando foram veiculados 13 (treze) Capítulos de Livros abordando o assunto, compreendendo a média estatística de 41,93\% em relação ao total das ocorrências sobre o material descrito, e 1 (um) texto publicado na $\operatorname{RBE}(3,22 \%)$.

O ano de 2003 registrou apenas uma publicação na RBE, ou seja, 3,22\% enquanto em 2004 foram computadas 2 (duas) sendo 1 (uma) em Textos do GT-11 ANPEd e 1 (uma) na qualidade de Textos de Outras Fontes, expressando o porcentual de 6,45\%, similar ao total dos trabalhos que circularam no interstício de 2001.

Em 2005 o fluxo das publicações experimentou uma elevação de 2 (duas) verificadas no ano anterior, para 4 (quatro). Destaque-se que os veículos privilegiados pelos autores teve no GT-11 ANPEd e na RBE os principais meios para fazer circular os produtos das pesquisas desenvolvidas.

No que se refere ao valor quantitativo dos trabalhos, o ano de 2006 contou com desempenho igual ao exibido no ano de 2005. Contudo, os meios de divulgação envolveram o GT-11 ANPEd, mas também emanaram de Textos de Outras Fontes, neste caso o Instituto de Estudos Avançados-USP, FEA-USP, ANAIS da 58 ${ }^{\text {a }}$ SBPC, distribuindo-se $25 \%$ para a primeira e $75 \%$ equitativamente às três restantes.

Concernente ao ano de 2007, verificou-se a publicação de apenas um trabalho referente ao tema da pós-graduação e orientação, sendo o mesmo gerado em Outras Fontes, neste caso, 
o GT-04 ANPEd, ocupando o porcentual de 3,22\% considerado o total dos textos que compuseram a amostra.

GRÁFICO 01 Procedência dos trabalhos segundo o veiculo $\theta$ ano de publicaçäo

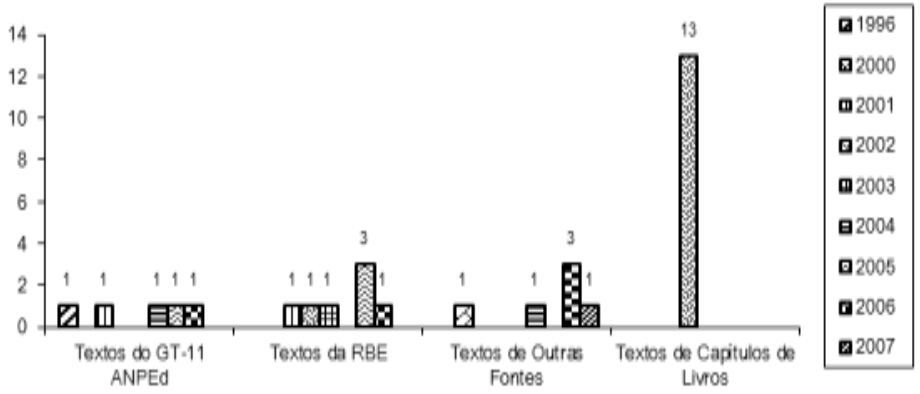

Logo, a circulação dos conhecimentos produzidos sobre a temática da pós-graduação e o processo de orientação das dissertações e teses, não apresentava uma regularidade entre o conjunto dos veículos que serviam de suporte para torná-los públicos. Depois do ano de 1996, somente em 2000 o tema retornou à agenda científica, ganhando espaço nas preocupações investigativas de diminuta parcela dos pesquisadores brasileiros.

Entre o intervalo histórico de 2000-2007, houve a maior incidência dos trabalhos publicados $(96,77 \%)$, sendo inexistente uma distribuição equitativa das pesquisas segundo os anos de sua ocorrência e o tipo de veículo escolhido. Basta perceber que grande parte da representatividade recaiu sobre os anos de 2002, 2005 e 2006, cujo quantitativo aglutinou $74,19 \%$ dos textos, dentre os quais 45,16\% tiveram sua veiculação em 2002 e os 12,90\% e $16,12 \%$ restantes no período de 2005 e 2006 , respectivamente.

É flagrante a escassez de pesquisas que se dedicam ao estudo da pós-graduação em sua articulação com o processo de orientação das dissertações e teses, como também se verifica a sazonalidade nos momentos em que elas ganham projeção nos veículos eleitos apropriados a sua circulação. Neste caso, os Capítulos de Livros detêm a supremacia tanto sobre a RBE e Outras Fontes, quanto ao GT-11 ANPEd.

\subsection{As Instituições de Ensino e território de origem dos Autores das Pesquisas}

São variadas as Instituições de onde provêm os autores das pesquisas que versam sobre a pós-graduação e o processo de orientação das dissertações e teses. Consultando o acervo bibliográfico catalogado, foi possível montar uma paisagem relacionando o território geográfico e a IES representada pelos investigadores.

As Universidades constituem os espaços difusores da produção científica, com predominância das instituições públicas sobre as particulares e confessionais. Porém, a participação de cada uma delas oscila conforme o tempo cronológico considerado. Em 1996, por exemplo, apenas uma IES registrou a ocorrência de trabalho, cuja publicação se efetivou na $20^{\mathrm{a}}$ Reunião Anual da ANPEd, realizada nesse mesmo período.

Quatro anos após esse registro, outro trabalho passou a circular, desta vez tendo a Região Sudeste como referência de origem. Esse panorama começou a se alterar gradativamente no ano de 2001, ocasião em que 2 (dois) trabalhos foram publicados, sendo um construído em parceria, procedente do Sudeste, e outro, do Sul.

No ano de 2002, dentre o total dos 14 (quatorze) trabalhos que ganharam publicidade, a representação regional ficou distribuída da seguinte forma: 78,92\% eram concentrados nas regiões Sudeste e Sul que acumulavam 5 (cinco) produções cada, enquanto 23,07\% escoavam do Nordeste, somando 3 (três) textos. Considerando-se essa composição 
segundo o sexo, tem-se que: no Sudeste 4 (quatro) eram mulheres e 1 (um) homem; no Sul os homens ficaram com 3 (três) enquanto as mulheres computaram 2 (dois); já no Nordeste elas englobavam toda a amostra. Desperta atenção também o tipo de veículo priorizado, posto que, nesse ano 12 (doze) eram Capítulos de Livros $(92,30 \%)$ e somente 1 (um) teve seu suporte publicitário na Revista Brasileira de Educação (7,69\%).

Para o ano de 2003, apenas um texto de autoria plúrima teve sua publicação, reunia 4 (quatro) autores, sendo 3 (três) mulheres e 1 (um) homem, o artigo veio a público pela Revista Brasileira de Educação.

Em relação ao ano de 2004, as regiões Sul e Sudeste voltavam à cena apresentando 1 (um) trabalho cada. É interessante notar que ambos foram construídos sob a forma de parceria, onde o primeiro congregou 2 (dois) autores e o segundo 3 (três). Cabe registrar que desse quantitativo o sexo feminino acumulava 3 (três) ocorrências (60\%) e o masculino 2 (duas) com média de $40 \%$. Nesse período, foram duas as fontes de publicação utilizadas, o GT-11 ANPEd $27^{\mathrm{a}}$ RA e Outras Fontes: Unesco-IESALC-IES.

Ao adentrar o ano de 2005, verificou-se que 4 (quatro) regiões marcavam presença na publicação, exceto o Norte, cada uma delas com 1 (um) texto. Embora tenha havido número razoável de trabalhos, dentre os 15 (quinze) autores envolvidos, 11 deles figuravam como protagonistas principais do sexo masculino, enquanto 4 (quatro) referia-se à participação da mulher nesse cenário da produção e circulação do conhecimento científico. Além disso, a Revista Brasileira de Educação amparou 3 (três) trabalhos (75\%), e o GT-11 ANPEd $28^{\text {a }}$ RA absorveu apenas 1 (um), correspondente a $25 \%$.

Tratando-se do ano de 2006, foram identificados 5 (cinco) textos científicos, dentre os quais as regiões Sudeste e Sul asseguraram 2 (dois) trabalhos cada, exibindo o valor estatístico de $80 \%$, enquanto o Nordeste figurou com 1 (um), alcançando a média de $20 \%$. Do total dos 9 (nove) autores envolvidos, 5 (cinco) pertenciam ao sexo masculino $(55,55 \%)$ e 4 (quatro) ao feminino (44,44\%). Verificou-se igualmente que sofreram ampla diversificação, tendo incidido a escolha dos autores sobre as Outras Fontes (60\%), sendo 1 (um) para cada uma delas o IEA-USP, a RAE-MG, e a 58 ${ }^{\mathrm{a}}$ RA SBPC; RBE n 31 e GT-11 ANPEd $29^{a}$ RA com a distribuição de $20 \%$ do total respectivamente.

Por fim, apenas um trabalho teve garantida sua publicação no ano de 2007 , de autoria feminina, originário da Região Sudeste, foi veiculado por Outras Fontes: GT-04 ANPEd $30^{\mathrm{a}} \mathrm{RA}$.

Assim, tornou-se evidente que as Universidades de onde provêm as pesquisas são localizadas na sua maioria na Região Sudeste (43,33\%), seguida do Sul (33,33\%), o Nordeste $(16,66 \%)$ e o Centro-Oeste $(3,33 \%)$. Por outro lado, os 31 (trinta e um) trabalhos examinados ficaram distribuídos entre 22 (vinte e duas) instituições, das quais 10 (dez) delas eram Federais (45,45\%), as Privadas somavam 7 (sete) com média de 31,81\%, as Estaduais 2 (duas) representando 9,09\%, e as Confessionais 3 (três) equivalente a 13,63\%. Foi possível identificar que entre os 52 (cinqüenta e dois) autores das produções científicas, mais da metade, ou seja, 27 pertenciam ao sexo feminino 51,92\%, enquanto 25 vinculavam-se ao tipo masculino $48,07 \%$. Notou-se, também que determinados textos passaram a ter sua confecção em parceria, razão pela qual não houve equivalência entre a autoria e o quantitativo dos trabalhos escolhidos para estudo, pois certos autores publicaram mais de uma vez, fator esse que contribuiu com expressivo aumento no número dos participantes.

No que concerne aos Veículos de circulação das pesquisas realizadas, tornou-se perceptível a variação no meio de divulgação dos trabalhos. Os textos propagados pelo GT-11 ANPEd tiveram incidência nas seguintes Reuniões Anuais: $20^{\mathrm{a}}, 24^{\mathrm{a}}, 27^{\mathrm{a}}, 28^{\mathrm{a}}$ e $29^{\mathrm{a}}$, evidenciando que mesmo no interior dessa Associação a temática relativa à pós-graduação e o processo 
de orientação das dissertações e teses transita na marginalidade, tendo como protagonistas uma reduzida parcela dos estudiosos. Destaque-se que na $30^{\mathrm{a}} \mathrm{RA}$ ocorreu uma publicação, contudo ela derivou do GT-04: Didática.

BELA n⿳01 : Distribuição dos trabalhos científicos, segundo IES,

Autoria, Região e Veículo de publicação 1996-2007

\begin{tabular}{|c|c|c|c|c|}
\hline Ano & IES & Autoria & Região & Veículo \\
\hline 1996 & & $\begin{array}{llll}\text { Emília } & \text { Maria } & \text { da } & \text { Trindade } \\
\text { Prestes } & & & \end{array}$ & & ANPEd $20^{a}$ RA \\
\hline 2000 & FE-UNICAMP & Dermeval Saviani & Sudeste & $\begin{array}{l}\text { Outras Fontes: } \\
\text { Revista } \\
\text { Diálogo } \\
\text { Educacional v. } 1 \mathrm{n}^{\circ} \\
1\end{array}$ \\
\hline \multirow[t]{2}{*}{2001} & UFRGS & $\begin{array}{lrrr}\text { Maria } & \text { Estela Dl } & \text { Pai } & \text { Franco; } \\
\text { Marília } & \text { Costa } & \text { Morosini } \\
\text { (ULBRA) } & & & \end{array}$ & Sul & ANPEd $24^{a}$ RA \\
\hline & PUC-SP & Bernadete Angelina Gatti & Sudeste & $\mathrm{RBE} \mathrm{n}^{\circ} 18$ \\
\hline \multirow{14}{*}{2002} & UFRJ & $\begin{array}{l}\text { Maria de Lourdes } \mathrm{de} \\
\text { Albuquerque Fávero }\end{array}$ & Sudeste & $\mathrm{RBE} \mathrm{n}^{\circ} 21$ \\
\hline & UFBA & Dora Rosa Leal & Nordeste & Capítulo de Livro \\
\hline & UFC & $\begin{array}{l}\text { Maria Inês Detsi de Andrade } \\
\text { Santos }\end{array}$ & Nordeste & Capítulo de Livro \\
\hline & URCA-CE & Cláudia Maria Moura Pierre & Nordeste & Capítulo de Livro \\
\hline & PUC-RIO & Zaia Brandão & Sudeste & Capítulo de Livro \\
\hline & $\begin{array}{l}\text { PPGEd- } \\
\text { FACIPAL-PR }\end{array}$ & Ana Maria Netto Machado & Sul & Capítulo de Livro \\
\hline & USP-SP & Antônio Joaquim Severino & Sudeste & Capítulo de Livro \\
\hline & UNISINOS-RS & Áttico I. Chassot & Sul & Capítulo de Livro \\
\hline & UNICAMP-SP & Dermeval Saviani & Sudeste & Capítulo de Livro \\
\hline & UFSC & Lucídio Bianchetti & Sul & Capítulo de Livro \\
\hline & UNIJUÍ-RS & Mario Osorio Marques & Sul & Capítulo de Livro \\
\hline & PUC-RS & Regina Zilbermann & Sul & Capítulo de Livro \\
\hline & $\begin{array}{l}\text { Faculdade } \\
\text { Pitágoras } \\
\text { MG }\end{array}$ & Cláudio de Moura Castro & Sudeste & Capítulo de Livro \\
\hline & UFC & Tereza Maria Frota Haguette & Nordeste & Capítulo de Livro \\
\hline 2003 & PUC-SP & $\begin{array}{l}\text { Bernadete Angelina Gatti; Marli } \\
\text { André, Osmar Fávero, Vera } \\
\text { Maria F. Candau }\end{array}$ & Sudeste & $\mathrm{RBE} \mathrm{n}^{\circ} 22$ \\
\hline \multirow[b]{2}{*}{2004} & UNIPLAC-RS & $\begin{array}{l}\text { Ana Maria Netto Machado; Ana } \\
\text { Carolina Lehmkuh (UFSC) }\end{array}$ & Sul & ANPEd $27^{a}$ RA \\
\hline & UNU/PUC-RJ & $\begin{array}{l}\text { José Raymundo Martins Romêo; } \\
\text { Christiane Itabaiana Martins } \\
\text { Romêo; Vladimyr Lombardo } \\
\text { Jorge }\end{array}$ & Sudeste & $\begin{array}{l}\text { Outras Fontes: } \\
\text { Unesco-IESALC- } \\
\text { IES }\end{array}$ \\
\hline 2005 & CFE-DF & $\begin{array}{l}\text { A Almeida Júnior; Newton } \\
\text { Sucupira ; Clóvis Salgado; José } \\
\text { Barreto Filho; Maurício Rocha e }\end{array}$ & $\begin{array}{l}\text { Centro- } \\
\text { Oeste }\end{array}$ & $\mathrm{RBE} \mathrm{n}^{\circ} 30$ \\
\hline
\end{tabular}




\begin{tabular}{|c|c|c|c|c|}
\hline & & $\begin{array}{l}\text { Silva; Durmeval Trigueiro; } \\
\text { Alceu Amoroso Lima; Anísio } \\
\text { Teixeira; Valnir Chagas; Rubens } \\
\text { Maciel }\end{array}$ & & \\
\hline & UFRN & $\begin{array}{l}\text { Betânia Leite Ramalho; Vicente } \\
\text { de Paulo Carvalho Madeira } \\
\text { (UFRN) }\end{array}$ & Nordeste & $\mathrm{RBE} \mathrm{n}^{\circ} 30$ \\
\hline & PUC-RJ & Menga Lüdke & Sudeste & $\mathrm{RBE} \mathrm{n}^{\circ} 30$ \\
\hline & UNIPLAC-RS & $\begin{array}{l}\text { Ana Maria Netto Machado; } \\
\text { Vania Alves }\end{array}$ & Sul & $\begin{array}{l}\text { GT-11 ANPEd } 28^{\mathrm{a}} \\
\text { RA }\end{array}$ \\
\hline & UFMG & Francisco César de Sá Barreto & Sudeste & $\begin{array}{l}\text { Outras } \\
\text { IEA-USP }\end{array}$ \\
\hline 2006 & UFRN & Betânia Leite Ramalho & Nordeste & $\mathrm{RBE} \mathrm{n}^{\circ} 31$ \\
\hline & UNIPLAC-RS & $\begin{array}{l}\text { Ana Maria Netto Machado; } \\
\text { Lucídio Bianchetti (UFSC) }\end{array}$ & Sul & $\begin{array}{l}\text { GT-11 ANPEd } 29^{a} \\
\text { RA }\end{array}$ \\
\hline & $\begin{array}{l}\text { UNIMONTES- } \\
\text { MG }\end{array}$ & $\begin{array}{l}\text { Geraldo Alemandro Leite Filho; } \\
\text { Gilberto de Andrade Martins } \\
\text { (FEA-USP) }\end{array}$ & Sudeste & 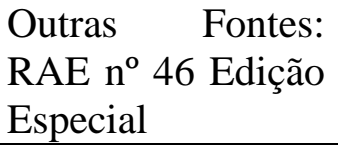 \\
\hline & UFSC & $\begin{array}{lrr}\text { Lucídio } & \text { Bianchetti; } & \text { Carolina } \\
\text { Fontoura } \quad \text { Cartana; } & \text { Letícia } \\
\text { Aparecida Martins } & \\
\end{array}$ & Sul & $\begin{array}{l}\text { Outras Fontes: } 58^{\mathrm{a}} \\
\text { Reunião Anual } \\
\text { SBPC }\end{array}$ \\
\hline 2007 & UNISANTOS & Suely Mazzilli & Sudeste & $\begin{array}{l}\text { Outras Fontes: } \\
\text { GT-04 ANPEd } 30^{\mathrm{a}} \\
\text { RA }\end{array}$ \\
\hline
\end{tabular}

Em relação à Revista Brasileira de Educação, percebeu-se que nesse Veículo os autores participaram em 5 (cinco) números: 18, 21, 22, 30 e 31, sendo que no ano de 2005 foram registradas 3 (três) incursões de autores na RBE $n^{\circ} 30$, permitindo adensar o quantitativo dos textos para 7 (sete) durante a série histórica.

Quanto aos Capítulos de Livros, notou-se que sua distribuição ficou concentrada em apenas três regiões brasileiras, onde o Sudeste captava a maioria, seguido pelo Sul e o Nordeste. Ademais, todas as obras analisadas foram publicadas no ano de 2002, o que evidencia a escassez desse tipo de veículo na socialização dos trabalhos.

No momento em que analisei as Outras Fontes, observei uma grande variação entre elas, porém, a única região contemplada foi a Sudeste, a qual arrematou todas as publicações efetivadas. Assim, houve a presença da Revista Diálogo Educacional, do Instituto de Estudos Avançados-USP, de relatórios da Unesco, da Reunião Anual da SBPC, e do GT04 da Reunião Anual da ANPEd.

As informações analisadas permitiram concluir que homens e mulheres participam em proporções desiguais na composição da autoria dos trabalhos científicos; as instituições que os absorvem são predominantemente públicas com sede no território da Região Sudeste; os autores envolvidos adotam os Capítulos de Livros como veículo predominante, mas assumem formatos diversos na propagação dos textos ao longo da série histórica.

\subsection{As temáticas expressas nos Títulos dos Trabalhos publicados}

A incursão na análise das temáticas priorizadas pelos autores dos textos selecionados resultou na aglutinação de três eixos específicos para os quais elas convergiam, a saber: Políticas de Pós-Graduação, Avaliação da Pós-Graduação, e Processo de Orientação das 
Dissertações e Teses. Desse modo, os 31 (trinta e um) trabalhos sofreram uma distribuição segundo seu pertencimento a cada uma delas.

GRÁFICO n? 02: Temáticas priorizadas pelos autores segundo o Veiculo de publicaçăo

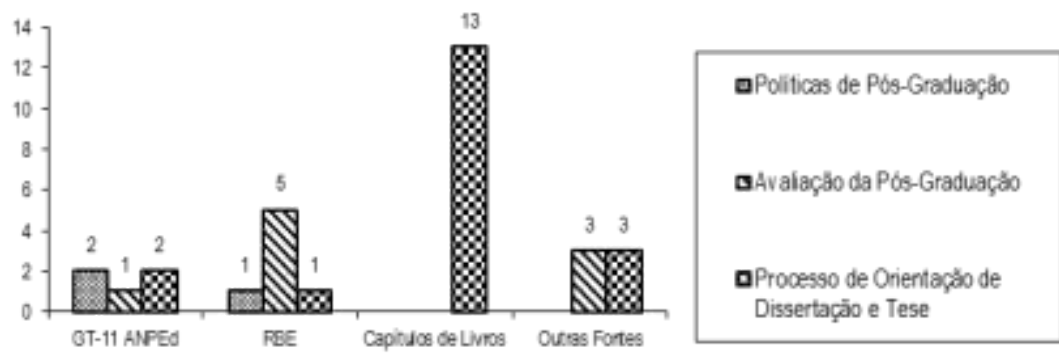

O eixo nomeado Políticas de Pós-Graduação, foi aquele com menor representatividade de trabalhos, ficando com 3 (três) textos $(9,67 \%)$; já o correspondente à Avaliação da PósGraduação, reuniu o total de 9 (nove) com média de 29,03\%; e o denominado Processo de Orientação das Dissertações e Teses, que somou 19 (dezenove) produtos, exibindo o valor estatístico de $61,29 \%$.

Considerando essa proporção e cruzando as informações referentes à Autoria, Sexo, Região e Veículo de divulgação, chega-se ao seguinte resultado:

Entre os autores que focalizam seus estudos sobre a temática Políticas de Pós-Graduação, ocorreu o predomínio exclusivo do sexo feminino. Devido ao exercício da produção em co-autoria, esses pesquisadores atingiram uma densidade superior ao número de trabalhos existentes. Por sua vez, as Regiões Sul (2) e Sudeste (1) tiveram a maior participação, com predomínio daquela 66,66\% sobre esta 33,33\%. Com relação ao Veículo, o GT-11 ANPEd obteve o mesmo desempenho apresentado por região, situação similar ocorreu com a RBE. Quanto ao eixo Avaliação da Pós-Graduação, a Região Sudeste deteve a hegemonia com 7 (sete) textos $(58,33 \%)$, seguida do Nordeste com 3 (três) trabalhos (25\%), o Sul e o CentroOeste ficaram com igual valor em 1 (um) $(8,33 \%)$ cada. O envolvimento desses pesquisadores também aconteceu em co-autoria, juntos somavam 26 (vinte e seis) intelectuais, sendo 10 (dez) mulheres $(38,46 \%)$ e 16 homens $(61,53 \%)$. Os Veículos priorizados recaíram em sua maioria 6 (seis) na RBE (50\%), no GT-11 ANPEd com um caso $(8,33 \%$ ), as Outras Fontes somaram 3 (três) (25\%) e os Capítulos de Livros foram inseridos na proporção de 2 (dois) $(16,66 \%)$.

Em se tratando do eixo Processos de Orientação das Dissertações e Teses, verificou-se que a Região Sul se destacou tendo o número de 12 (doze) protagonistas na autoria das pesquisas, o que corresponde ao porcentual de 54,55\%. O Sudeste contribuiu com 8 (oito), ficando em 36,36\%, e o Nordeste participou com 2 (dois) estudiosos e média de 9,09\%. Mais uma vez as publicações em co-autoria envolveram 4 (quatro) dos 19 (dezenove) textos que circularam, sendo 13 (treze) com participação individualizada $(59,09 \%)$ e 9 (nove) autores em colaboração $(40,90 \%)$. Examinando-se a variável sexo, notou-se que as mulheres fizeram a maior representatividade com 12 (doze) ocorrências (54,54\%), enquanto os homens influíram na amostra com 10 (dez), respondendo por 45,45\%. Além disso, no que se refere ao Veículo utilizado para dar visibilidade às investigações, ficou assim distribuído: 10 (dez) Capítulos de Livros (66,66\%), 3 (três) oriundos de Outras Fontes (20\%) e 2 (dois) provenientes do GT-11 ANPEd (13,33\%).

Percebeu-se que quando se tratava de analisar as Políticas de Pós-Graduação, houve a presença marcante das mulheres do Sul, utilizando-se do GT-11 ANPEd como principal 
referência para publicação. No entanto, as pesquisas dirigidas para a Avaliação da PósGraduação, evidenciaram outra tendência na qual a Região Sudeste alcançou o ponto mais elevado, os homens detiveram a maioria e o Veículo de publicação ficou com a supremacia da RBE. Já aqueles textos cujos autores discutiram o Processo de Orientação das Dissertações e Teses, o Sul voltou a se destacar como espaço territorial de maior produtividade, o sexo feminino teve maior expressividade e os Capítulos de Livros foram eleitos o meio de divulgação dos resultados daqueles estudos desenvolvidos pelos intelectuais.

\subsection{As finalidades das pesquisas realizadas}

Com relação às Finalidades das Pesquisas consubstanciadas nos trabalhos publicados, os autores ancorados no eixo das Políticas de Pós-Graduação assentaram os objetivos de seus estudos nas seguintes ordens de prioridades: dois textos versaram sobre o estudo das trajetórias e rumos da pós-graduação $(66,66 \%)$; outro se ateve à definição da natureza e objetivos dos cursos de pós-graduação $(33,33 \%)$. Assim, embora partam do mesmo campo analítico, os estudos ramificam suas finalidades, posto haver distinção entre os objetos e os interesses epistemológicos dos investigadores dedicados ao tema.

Dentre os autores que convergiram para o eixo Avaliação da Pós-Graduação, os fins de suas produções pontuaram as diretrizes, estratégias e lógicas da pós-graduação (1); trajetória, perspectivas e estudos da pós-graduação (3); importância do papel do Estado na condução das ações no campo da educação (1); crescimento e condições atuais dos cursos de pós-graduação (2); produção de conhecimento, poderes e práticas na pós-graduação (1); e os modelos de avaliação CAPES (1).

Neste caso, notou-se que a trajetória, perspectiva e estudos da pós-graduação consistiram na temática de maior incidência, absorvendo $40 \%$ do total. Em segundo lugar, em termos de representatividade, ficou o crescimento e condições atuais da pós-graduação, conformando a média de $20 \%$, enquanto modelos de avaliação; produção de conhecimento, poderes e práticas; diretrizes, estratégias e lógicas; intervenção do Estado no campo das ações de políticas educacionais; estiveram representadas com $10 \%$ cada.

Convergindo para o eixo relacionado ao Processo de Orientação das Dissertações e Teses, o conjunto dos textos inspecionados permitiu extrair as seguintes evidências das finalidades propostas pelos autores das pesquisas: discutir a orientação e escrita de dissertações e teses (4); analisar a relação orientador e orientando, modelo e trajetória da pós-graduação (8); perceber as influências dos órgãos de avaliação e financiamento na dinâmica da pós-graduação (1); identificar os reflexos da pós-graduação na orientação de dissertações e teses (1); analisar os processos de pesquisa e percursos metodológicos das dissertações e teses (3); socializar experiências vividas na condição de orientador (2).

Depreende-se desse eixo que a relação orientador e orientando, modelo e trajetória da pósgraduação, despertou maior interesse na comunidade dos pesquisadores, ficando com $42,10 \%$ das ocorrências. Já a orientação e escrita de dissertações e teses teve acentuada participação, acumulando o porcentual de $21,05 \%$, seguida por aquelas produções que enfocaram os processos de pesquisa e percursos metodológicos das dissertações e teses, com $15,78 \%$. De outra parte estavam representadas as experiências vividas na condição de orientador (10,52\%), as influências dos órgãos avaliadores e de financiamento na dinâmica da pós-graduação $(5,26 \%)$, e os reflexos da pós-graduação na atividade de orientação $(5,26 \%)$, que somadas atingiram $21,04 \%$.

Resguardadas as devidas proporções acima identificadas, verifica-se que também aqui as pesquisas incidentes sobre os processos de orientação apresentaram pluralidade de temas e 
elegeram objetos de estudos diferenciados. Isto revela a pertinência desse nascituro, e ainda intrigante, mas promissor, campo de investigação.

\subsection{Principais questões investigativas formuladas pelos autores}

Quando se tratou da dimensão Questões Investigativas, a análise dos trabalhos explicitou a existência de uma diversidade de interrogações formuladas pelos autores das pesquisas, conforme aglutinação realizada segundo os eixos em que se distribuíram os textos consultados.

Desse modo, os artigos vinculados ao eixo da Política de Pós-Graduação, incorporaram perguntas direcionadas para saber o que está acontecendo com a expansão da pósgraduação; quais as influências do processo de globalização no universo da educação e da pós-graduação; a necessidade de implantar e desenvolver o regime e cursos de pósgraduação no ensino superior.

Por outro lado, os trabalhos acadêmicos focados no eixo Avaliação da Pós-Graduação, procuraram iluminar questões sobre: a diversidade de diretrizes e estratégias é uma tendência na educação superior que marca atualmente a pós-graduação; a pós-graduação se volta à formação acadêmica e formação de pesquisadores; luta pela implementação da pósgraduação no Brasil; a pós-graduação é o setor educacional de melhor desempenho que teve planejamento e financiamento do Estado; provocar discussões com coordenadores e colegiados de pós-graduação.

Além dessas reflexões, questionou-se sobre qual a natureza e o propósito dos estudos na pós-graduação em um momento de aceleradas mudanças; que valor tem para as pessoas e a sociedade; ter-se-á atingido a terra prometida na pós-graduação; a quem e para quem se destina a pós-graduação no sistema social brasileiro; qual o empenho da pós-graduação na luta pela universalização e qualidade da educação.

Com relação às produções científicas que se concentraram no eixo Processo de Orientação das Dissertações e Teses, verificou-se que seus autores estavam preocupados em pesquisar os entraves encontrados pelos orientandos no exercício de formar pesquisadores; os impactos das mudanças paradigmáticas implementadas pela CAPES ao modificar o modelo de avaliação em 1990; qual o significado da relação orientador-orientando; como orientadores de dissertação e teses em Programas de Pós-Graduação em Educação realizam suas funções de caráter emancipatório frente às demandas regulatórias das políticas vigentes.

Nesse mesmo eixo, igualmente converteu-se em alvo de indagação o entendimento de quais os meios utilizados e as estratégias que estão sendo empregadas para contribuir com os orientandos a fim de que escrevam seus trabalhos e os divulguem; situar os principais reflexos dos programas de pós-graduação estrangeiros sobre a pós-graduação do Brasil; o processo de construção da pesquisa raramente é linear, claro, direto; definição do objeto de pesquisa, do arcabouço teórico e da metodologia de um projeto de tese; percurso para elaboração e realização do projeto de dissertação; o que viabiliza uma boa pós-graduação; a atividade do orientador das teses e dissertações constitui a figura que desempenha papel crucial, na academia, no processo subjetivo de tornar-se autor; a pós-graduação, no Brasil, é uma experiência consolidada, tendo atingido significativo êxito, com bons resultados a contabilizar.

Além dessas perguntas outras foram apresentadas visando esclarecer que o escrever é realmente um dos mais significativos problemas na elaboração de textos acadêmicos; há um caráter idiossincrático da experiência de orientação; a orientação constitui problema central do Sistema de Pós-Graduação no Brasil; a pesar de a elaboração e orientação de 
trabalhos de final de cursos de pós-graduação stricto sensu ser um processo complexo, do ponto de vista individual do aluno, da relação que se estabelece entre orientador e orientando, do produto final, o mesmo não tem recebido a devida atenção de parte dos pesquisadores; a produção científica, sobretudo discente, dos programas de pós-graduação stricto sensu, vem sendo prejudicada por dois fatores interligados: a incompetência metodológica dos orientadores e sua inabilidade no cumprimento dessa obscura função; a expansão da pós-graduação nos anos de 1970, criou uma situação nova no quadro do ensino brasileiro: a relação acadêmica entre orientador e orientando.

Notou-se que no universo acadêmico da pós-graduação, cresce o interesse dos pesquisadores pelo campo do Processo de Orientação de Dissertações e Teses. Contudo, essa movimentação intelectual em torno desse objeto constitui fenômeno recente que desafia o exercício da curiosidade da comunidade científica, assim como tem provocado o aumento no volume de escritos a respeito do assunto.

As argüições formuladas pelos autores dos trabalhos que deram substrato a essa pesquisa, demonstraram o quanto a formação pós-graduada e, nessa seara, a relação pedagógica estabelecida entre orientador e orientando, abriga fenômenos educativos pouco explorados. Abrir o sarcófago da ambiência de formação científica significa descortinar outros horizontes temáticos na composição da escrita da história da pós-graduação brasileira. $\mathrm{O}$ difícil será encontrar quem esteja disposto a apresentar inquérito sobre esse promissor território acadêmico!

\subsection{Características da Metodologia Empregada na construção dos trabalhos acadêmicos}

No exame dos trabalhos estudados foi possível identificar certos traços característicos das estratégias metodológicas adotadas pelos pesquisadores com intuito de desenvolver suas respectivas investigações.

Considerando-se os três eixos em que fora subdividido o conjunto das produções catalogadas, ficou evidente que aqueles textos vinculados às Políticas de Pós-Graduação assentaram suas escolhas metodológicas na apreciação de documentos oficiais associados à pesquisa bibliográfica, análise de dados extraídos da CAPES, QUALIS e nos sites dos Programas de Pós-Graduação, assim como na pesquisa documental combinada com estudo da experiência vivida nesse nível acadêmico. Convém ressaltar que um dos autores não referiu o itinerário de sua investigação.

Quando volvi o olhar para o eixo Avaliação da Pós-Graduação, percebi que as estratégias investigativas ficaram concentradas no estudo histórico-analítico das políticas de diversificação; no tratamento teórico do conceito de pós-graduação e sua história, situação atual, tendências e perspectivas; priorizou estudos consubstanciados em documentos oficiais, com coleta de dados realizada em sites eletrônicos; dedicaram-se a apresentar propostas e metas definidas nos Planos Nacionais de Pós-Graduação para resgatar a história do planejamento e organização da pós-graduação, apresentando resultados e situação atual mediante estudo analítico-descritivo.

Também ocorreram trabalhos cujos autores escolheram a análise específica de documentos oficiais, bem como a pesquisa bibliográfica. Em 2 (dois) textos os autores não chegaram a descrever os passos operacionais utilizados na execução da pesquisa.

Quando abordei o eixo Processo de Orientação das Dissertações e Teses, identifiquei que os estudos se subdividiram em quatro tendências metodológicas: estudos teóricos, relatos de experiências, estudo bibliográfico e uso de narrativas. 
No âmbito dos trabalhos que anunciaram preocupações de caráter teórico, sua incidência consistiu na análise das concepções e modalidades de orientação de dissertações e teses, suas metamorfoses e impactos nas produções acadêmicas. Por outro lado, adotou-se também o estudo teórico sobre a natureza da pós-graduação na produção do conhecimento; as exigências epistemológicas, metodológicas e técnicas do processo de investigação; as práticas e posturas acadêmico-científicas na produção das teses e dissertações; assim como a significação da política de pesquisa em educação. Porém, verifiquei a existência de autores examinando a incompetência metodológica do orientador da dissertação e tese e seu relacionamento com o aluno, propondo, inclusive, princípios cruciais ao rigor científico, associados ao relacionamento ótimo entre orientador e orientando.

Em relação às pesquisas metodologicamente respaldadas nos relatos de experiência, notei que o alvo incidiu na descrição de experiências pessoais na construção da dissertação e da tese em termos da escolha do objeto, definição do tema, formulação dos objetivos, construção da hipótese, coleta e análise dos dados.

Já os estudos bibliográficos apresentaram uma combinação com o uso de narrativas sobre a experiência na construção do projeto de tese, bem como se associaram a tais procedimentos a inspeção de textos sobre o processo de orientação e autoria, como também pesquisas coladas a bibliografias enfocando a formação universitária, o escrever e as competências e atribuições do orientador, e outras fincadas à análise histórica comparativa do fenômeno da orientação na pós-graduação.

Quanto às narrativas, houve um conjunto de trabalhos dedicados ao uso das narrativas como explicador e produtor de conhecimentos, mediante aplicação de entrevistas com orientadores em diferentes tempos de carreira e grupos focais de mestrandos e doutorandos. Também ocorreu a construção de trabalhos apoiados em avaliação qualitativa por meio de entrevistas estruturadas aplicadas a orientandos e orientadores, tendo havido pré-teste dos instrumentos. Outros autores investiram no estudo da pós-graduação combinando-o com entrevistas dirigidas a orientadores e coordenadores, leitura e exame de obras com aplicação de entrevistas.

Com base nas observações e análises dessa dimensão, verifiquei uma diversificação nas escolhas metodológicas incorporadas aos escritos dos autores. Tal fenômeno ocorreu em função da variação nos temas priorizados, assim como nos problemas de pesquisa e nas finalidades pretendidas com os estudos. Todavia, em determinados trabalhos a metodologia nem sequer chegou a ser referida.

Embora as práticas investigativas convencionais realizadas por meio dos estudos que priorizam os documentos oficiais ainda exerçam certo fascínio sobre seus autores, há investigações baseadas em outros suportes documentais que referendam trabalhos de natureza teórica e pesquisas bibliográficas. De outra parte, cresce entre os investigadores a tendência para o uso de informações e conhecimentos situados na base de dados das agências de fomento à pesquisa e dos Programas de Pós-Graduação, assim como a consulta a periódicos, relatórios, dissertações e teses disponíveis ao acesso nos arquivos eletrônicos que podem ser consultados via internet.

Foram identificados também grupos de trabalhos que assumiram como linha metodológica o recurso ao enlace da pesquisa bibliográfica com o relato de experiência, tendo como sujeitos informantes os orientadores, coordenadores de Programas de Pós-Graduação, orientando e a análise do fenômeno da orientação das dissertações e teses numa perspectiva da autoformação vivida pelos autores dos textos consultados. Além disso, cabe destacar que o uso das narrativas ganhou representatividade entre as escolhas metodológicas assumidas nesses escritos acadêmicos. 


\subsection{Fontes Históricas como suportes documentais nutrientes das pesquisas}

Tratando-se do tipo de Fonte Histórica utilizada para dar subsídio ao enredo dos textos produzidos pelos autores estudados, foram encontrados diferentes suportes dos quais os pesquisadores extraíram os vestígios das informações para compor seus escritos, conforme mapa gráfico abaixo:

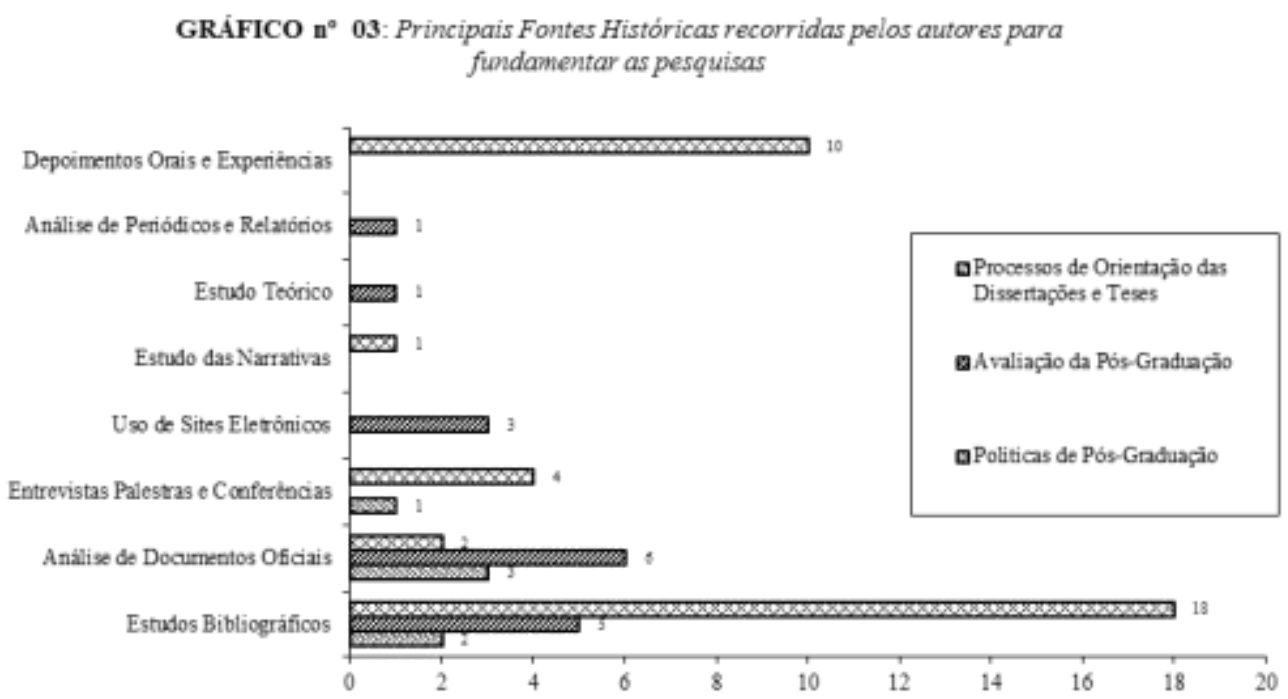

Enquanto no eixo das Políticas de Pós-Graduação houve prioridade à análise de documentos oficiais, essa tendência fora acompanhada dos estudos bibliográficos e do recurso a entrevistas, palestras e conferências. Considerando-se o número dos três trabalhos consultados, notou-se que os mesmos incidiram sobre diversificadas fontes de informação, tendo ocorrido, portanto, na maioria dos casos, uma combinação entre elas.

Quanto ao eixo que considera a Avaliação da Pós-Graduação, os trabalhos aí aglutinados extraíram a seiva nos documentos oficiais, com grande repercussão sobre as bibliografias, como também no uso de sites eletrônicos, no estudo teórico e na análise de periódicos e relatórios. Tornou-se flagrante a assimetria entre o número de trabalhos existentes (9) e a multiplicidade das fontes históricas (16) que deram apoio às reflexões desenvolvidas pelos autores. Tal fato se justifica em função da inserção, no mesmo texto, de suportes documentais diversos, mas fundamentais na construção do raciocínio dos pesquisadores que os mobilizaram.

No tocante aos trabalhos que discutiram o Processo de Orientação das Dissertações e Teses, tornou-se possível identificar a hegemonia exercida pelos estudos bibliográficos, seguidos dos depoimentos orais e experiências, das entrevistas palestras e conferências, da análise documental e do estudo das narrativas. Nesse âmbito em particular, o acúmulo dos trabalhos indicava o total de 19 (dezenove) textos, porém, foram notificadas 35 (trinta e cinco) escolhas entre o leque de fontes apresentadas. Essa composição permitiu constatar, também, que os pesquisadores matizaram suas investigações, de modo a poder decifrar os problemas de pesquisa conformadores das temáticas eleitas para reflexão científica.

Os estudos bibliográficos e a análise de documentos oficiais marcaram presença nos três eixos em que foram distribuídos os textos. Contudo, o uso de entrevistas, palestras e conferências reverberou tão-somente naqueles que explanaram a Política de PósGraduação e o Processo de Orientação das Dissertações e Teses, com a presença neste último do estudo das narrativas e dos depoimentos orais e experiências. 
Em se tratando das investigações vinculadas à Avaliação da Pós-Graduação, quando considerada individualmente, sua incidência repercutiu no uso de sites eletrônicos, o estudo teórico e na análise de periódicos e relatórios.

Verifica-se, portanto, que as opções por determinados tipos de fontes para subsidiar a produção da verdade histórico-científica, requer sincronia entre a temática escolhida, as opções teórico-valorativas dos pesquisadores, os problemas que fustigam sua curiosidade, as finalidades das investigações e as tecnologias metodológicas adotadas. Com base nessa relação as fontes históricas serão julgadas (im)pertinentes na captura dos acontecimentos e fatos por meio dos vestígios que nutrem a composição dos textos escritos.

\subsection{A delimitação do Período Histórico abrangido pelos estudos}

Com relação à definição do Período Histórico adotado nos textos analisados nesta pesquisa, foi possível constatar a existência de trabalhos que privilegiaram um olhar mais estrutural na tentativa de compreender em profundidade os fenômenos na sua longa duração. Outros se ativeram em momentos conjunturais, de modo a perscrutar seus objetos segundo os ciclos de manifestação. Por outro lado, ocorreram estudos dedicados ao tempo curto, caracterizado pelo acontecimento imediato e o plano da superfície ${ }^{2}$.

GRÁFICO n $^{\circ} 04$ : Dimensão dos trabalhos segundo o

Tempo Histórico priorizado pelos seus autores
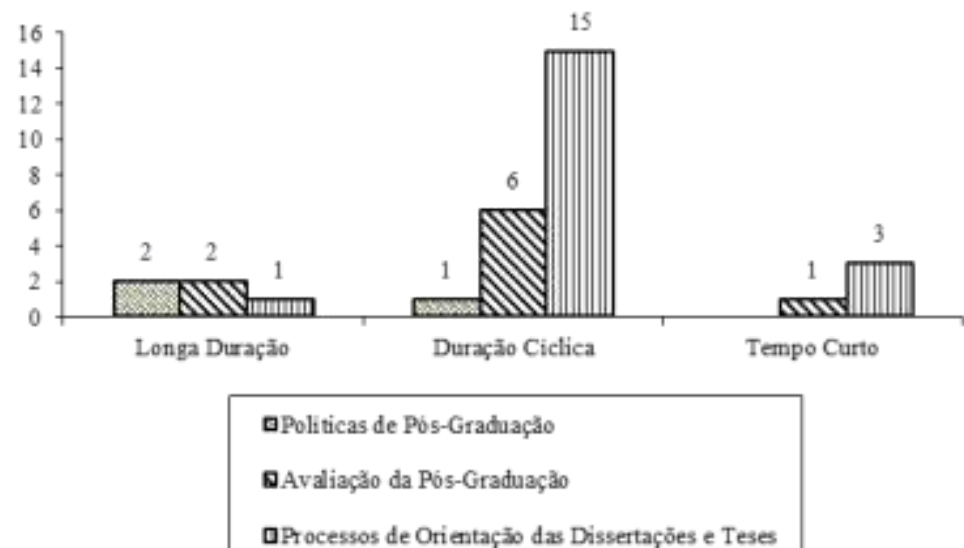

Entre os artigos que compõem o eixo das Políticas de Pós-Graduação, dois deles elegeram a longa duração como referência temporal: um focalizou o Século XIX ao XXI e outro se ateve aos anos de 1876-1965. Um terceiro trabalho fixou sua abrangência entre o intervalo de 1970-1996.

Quando analisei os artigos contidos no eixo Avaliação da Pós-Graduação, pude constatar que do total dos 9 (nove) trabalhos escritos, em dois deles os autores concentraram a investigação no tempo histórico de longa duração (22,22\%), com ênfase nos anos de 1823 2000 e 1889-2004, enquanto $1(11,11 \%)$ se dedicou ao estudo da temática no tempo curto, ou seja, abrangendo os anos de 1998-1999, porém, 6 (seis) pesquisadores assentaram suas análises considerando a duração cíclica $(66,66 \%)$. Neste caso em particular, as produções tiveram suas temporalidades distribuídas entre 1960-2005.

Em relação ao total dos dezenove textos concentrados no eixo Processos de Orientação das Dissertações e Teses, verifiquei que apenas um trabalho fora desenvolvido tendo como parâmetro a longa duração $(5,26 \%$ ), outros 3 (três) respaldaram-se no tempo curto $(15,78 \%)$, enquanto a maioria absoluta dos autores (15) dedicou-se a considerar a duração cíclica dos fatos e acontecimentos relacionados ao tema investigado $(78,94 \%)$. 
Considerando-se o total dos 31 trabalhos estudados, sobressai o entendimento de que há um número razoável dos autores que focalizaram seus objetos no nível da longa duração $(16,12 \%)$. De outra parte, verificou-se a presença de textos cujo lapso histórico recaiu no tempo curto $(12,90 \%)$. Todavia, a maior representatividade estatística atingiu as produções acadêmicas articuladas em torno da duração cíclica $(70,96 \%)$.

Percebe-se que o tempo histórico não constitui uma categoria aprisionada em cronologias rígidas, pois sua construção se faz em função dos temas escolhidos, assim como dos vestígios relacionados aos acontecimentos e fatos históricos julgados significativos para elucidar o fenômeno sob análise. Assim, os elementos cronológicos são deveras importantes na verificação do movimento do objeto de estudo ao longo do tempo e suas repercussões nos espaços geográficos e institucionais, em particular as alterações que promove sobre a cultura e os sujeitos tocados por sua dinâmica.

\subsection{Principais resultados oriundos das pesquisas realizadas}

A última dimensão que procurei apreender durante o exame dos trabalhos publicados foi aquela referente aos Principais Resultados formulados pelos pesquisadores.

Os autores cujas produções foram aglutinadas no eixo Políticas de Pós-Graduação, revelaram que "precisam ser feitas análises e questionamentos sobre os resultados da indução promovida pela CAPES a partir das rigorosas avaliações implantadas desde meados da década de 1990". Por outro lado, indicaram que "a avaliação tem induzido novos padrões de conduta nos pesquisadores e tem obtido parte dos resultados esperados de maneira rápida, o que poderíamos chamar de eficácia". No entanto, ficou evidente que "A eficácia da ação indutiva da avaliação da CAPES tem tido bons resultados, mas tem sido regida por um princípio - o mais tradicional possível - centrado em punição e premiação" (MACHADO \& ALVES, 2005).

Nesse sentido, os trabalhos indicam a necessidade de se "romper com tendências centralizadoras e anacrônicas para os novos dias". Postula-se que "A avaliação das agências financeiras, ainda quando possa parecer parcial e ameaçadora aos olhos de muitos, serve como elemento de impacto e de reflexão sobre os nossos comportamentos, nem sempre o mais adequado". De igual modo admite-se que a avaliação CAPES "Serve como elemento de reflexão sobre o papel e compromisso do Estado com a educação e da constatação das nossas fragilidades regionais. Serve por fim para despertar nas pessoas envolvidas com o ensino superior a vontade de mudar" (PRESTES, 1996).

Outro texto revela que "O mérito do sistema... está em que a pós-graduação não se limita apenas ao preparo de uma tese doutoral ou uma dissertação de mestrado. Compreende uma série de cursos a que está obrigado o aluno, cobrindo ampla extensão do campo de conhecimento escolhido". Além disso, pondera que "Essa organização sistemática da pósgraduação tem ainda a vantagem de oferecer o máximo de assistência e orientação ao aluno em seus estudos, sem prejuízo de liberdade de iniciativa que lhe é essencial". Diz ainda que "O programa de estudos do mestrado e doutorado se caracterizará por grande flexibilidade, deixando-se ampla liberdade de iniciativa ao candidato que receberá assistência e orientação de um diretor de estudos". Por fim menciona preocupações com uma composição curricular da qual "constará o programa, sobretudo, de seminários, trabalhos de pesquisa, atividades de laboratório com a participação ativa dos alunos" (ALMEIDA JÚNIOR, et. al., 2005).

No eixo da Avaliação da Pós-Graduação a universidade é pensada como "instituição de diversidade" envolvida por uma realidade "multicultural", razão pela qual "a transposição das políticas públicas para práticas traduzem diferentes lógicas, não só entre agências 
governamentais e a comunidade científica mas, também, entre os interlocutores que perfazem esta comunidade na busca de 'harmonizações' de interesses distintos, mesmo que a busca tenha caráter provisório". Em face dessas constatações, admite-se que "historicamente, no Brasil, a concepção de ciências nos órgãos governamentais tem privilegiado o pensamento das ciências positivas em detrimento das ciências humanas" (FRANCO \& MOROSINI, 2001).

Quando do início da pós-graduação brasileira verificou-se que "os professores, via de regra, supunham um razoável grau de autonomia dos mestrandos esperando que eles definissem o próprio objeto de investigação e, ato contínuo, escolhessem o orientador adequado para acompanhá-lo em sua pesquisa" (SAVIANI, 2000).

Em outro trabalho, ficou evidenciada a necessidade de a política de pós-graduação "resolver a assimetria no interior das instituições". Considerando-se a flexibilidade como característica desse sistema de formação do pesquisador "os créditos não deveriam ser o núcleo da formação dos pós-graduandos, mas sim atividades complementares. O importante passa a ser a adaptação do currículo ao perfil dos alunos". Para tanto é importante que "no lugar dos créditos, as práticas de pesquisa, a pesquisa em laboratórios e a participação em grupos de pesquisa com atividades fixas (contabilizadas como créditos cursados) seriam mais adequados à formação do pesquisador" (ROMÊO, J. R. M. et ali., 2004).

Para outros autores, "o paradigma da formação de educadores-pesquisadores comprometidos com a transformação social" ainda está em consolidação. Por seu turno "a estratificação social continua impedindo que a pós-graduação ofereça uma contribuição mais efetiva e marcante para a construção de um projeto nacional de educação básica e superior com qualidade e oportunidades para todos". Nesses novos tempos, é preciso enfrentar os seguintes desafios: questionar os riscos do predomínio da perspectiva produtivista que perpassa todas as áreas; corrigir as disparidades regionais; combater a desvalorização dos pesquisadores em educação; desinteresse governamental (RAMALHO, 2006).

Em função das características assumidas pelo modelo homogeneizador de avaliação da CAPES, há autores indicando que os procedimentos avaliativos precisam ser revestidos de uma "função formativa, a avaliação não deve ser usada para descredenciar programas, mas para detectar os problemas eventualmente existentes e para definir as medidas apropriadas ao seu aperfeiçoamento". Nessa perspectiva, "é preciso redefinir com maior profundidade sobre os fundamentos políticos do modelo atualmente vigente, seus objetivos e impacto à luz das variadas e variáveis necessidades nacionais" (GATTI, et ali., 2003).

Igualmente foi possível perceber autores que delinearam tendências no campo da pósgraduação, evidenciando que "além da seletividade social, a evasão também se mostra alta". Por outro lado, "cada vez mais os estudantes desse nível têm que arcar com os custos deste ensino e dividir seu tempo entre trabalho e estudo". Além desses aspectos, notou-se que "a inflexibilidade curricular cerceia oportunidades, especialmente para os alunos trabalhadores" (GATTI, 2001).

No ambiente da pós-graduação ainda estão presentes vestígios de uma "educação bancária e cartorial que recebemos, muitos professores da pós-graduação se constituíram em patrões e capatazes de um poder acadêmico que reproduz o poder exercido numa sociedade de classes". Assim considerados, "Muitas vezes os pós-graduandos são apenas alunos, no sentido etimológico do termo, e os professores são os detentores do poder e do saber, no domínio do capital intelectual. Em vez de relações dialógicas numa comunidade de trabalho acadêmico, continuam sendo mantidas relações de dominação" (RAMALHO; MADEIRA, 2005). 
Quando se tratou dos textos vinculados ao eixo Processos de Orientação das Dissertações e Teses, as conclusões dos trabalhos apontaram para os seguintes aspectos:

Embora haja uma tradição na formação de professores, a formação de pesquisadores é um tema recente. Contudo, o trabalho de orientação é marcado por dramas ou questões pessoais que fazem o orientando sumir; lacunas em orientandos vindos de outras áreas; problemas relacionados à escolha do orientador; angústias do orientador; tempo escasso para orientação; dificuldades em relação à escrita de mestrandos; teimosia, cabeça dura, sabe-tudo, vieses políticos ou religiosos. Verifica-se que a construção de uma tese ou dissertação "exige convergência de praticamente todas as energias vitais... tanto da parte do orientando como do orientador". Dessa maneira, admite-se que a orientação como "um ponto nodal e estratégico, que extrapola as relações orientador-orientandos", sendo a formação dos pesquisadores influenciada pelas políticas de pós-graduação, pesquisa e produção científica (MACHADO, A. M. N; BIANCHETTI, L., 2004).

Machado e Bianchetti (2006) consideram que o processo de orientação representa a "atividade central da formação de pesquisadores". De acordo com esses autores, "Existe considerável experiência acumulada, mas pouco socializada entre os pares, sobre os processos de formação de pesquisadores, de orientação e de produção de resultados qualificados". Quando do predomínio do paradigma de formar professores, buscava-se qualificar as atividades de ensino e formação profissional nas Universidades brasileiras", com prioridade, sobretudo, ao "avanço do número de titulados". No modelo atual voltado para a formação de pesquisadores, "o valor de um pesquisador está em leilão e se mede pelo quanto 'vende' seus produtos". Assim, torna-se forçoso admitir que "a era de produtividade que vivemos, atualmente impõe aos pesquisadores uma lógica desumana". Portanto, "a submissão a uma autonomia controlada, não é a mais alentadora das perspectivas para quem se dedica ao trabalho de formação e qualificação das novas gerações".

No trabalho de Leite Filho e Martins (2006), são destacados certos aspectos relacionados ao processo de orientação indicando que "os orientadores tendem a valorizar características técnicas dos orientandos, enquanto os orientandos valorizam as características afetivas e pessoais dos orientadores". No entendimento desses pesquisadores, "A falta de sistematização e o ambiente de autocracia provocam nos orientandos sentimentos de insegurança, angústia e solidão, decorrentes da falta de contato, da conseqüente falta de apoio, de direcionamento e de retorno dos orientadores". A melhoria dessa relação pedagógica passaria pela implementação das seguintes medidas: criação de espaços acadêmicos de discussão e reflexão sobre o que se espera de uma dissertação ou tese e sobre a qualidade da produção científica dos programas; utilização do modelo de orientação coletiva criando-se a figura do co-orientador; realização de seminários entre orientadores e orientandos; utilização de noções de relacionamento interpessoal e aconselhamento e orientação psicológica; adequar procedimentos e condutas em função das características pessoais, intelectuais e comportamentais; encontros dos orientandos do mesmo orientador; acompanhamento dos orientandos pelos orientadores durante as disciplinas no programa visando a otimização na utilização do tempo; incentivar os orientandos a criar o hábito de participarem de sessões de defesas de teses e dissertações.

Para Cartana et. al. (2006), há uma nova cultura na pós-graduação que afeta o "processo de formação de mestres e doutores". As "formas inovadoras" criadas por orientadores e coordenadores "vem garantindo a produção exigida - conclusão de teses e dissertações em menos tempo, participações em congressos, etc. - em termos quantitativos". Todavia, fica evidente para esses autores que "juntamente com tantas vantagens, acumulam-se perdas, particularmente na qualidade dos trabalhos". Por outro lado, verificaram que "o processo 
da orientação, da escrita e da publicação é um fator de desgaste, uma vez que expõe, socializa algo que ou ocorria muito no plano privado ou era pouco divulgado". Em que pese essas dificuldades, tem ocorrido "melhorias qualitativas na Pós-Graduação em Educação: maior disponibilidade e melhor utilização de infra-estrutura de base informática, organização de grupos de pesquisa interinstitucionais, orientação a distância, relação mais qualificada da Pós-Graduação com a Graduação, incremento na socialização das produções".

A pesquisa desenvolvida por Lüdike (2005) revelou que "a pós-graduação visa a sólida formação científica e exige assistência máxima e orientação ao aluno, respeitando sempre sua liberdade e iniciativa pessoal (...) o orientador tem papel importante no percurso acadêmico dos seus orientandos". Para a estudiosa, "dirigido por um orientador, o processo de orientação pode acontecer por meio de atividades comuns, de estudos e de seminários ao redor de seu interesse de pesquisa". Destaca ainda que "os trabalhos de pesquisa devem estar engajados em projetos ligados aos dos orientadores", devendo haver "valorização do aspecto teórico do trabalho de dissertação ou tese", bem como se requer que o pesquisador adquira "formação plural em diferentes domínios teóricos, permeada por linhas e grupos de pesquisa", tendo como subsídio as bolsas de auxílio ao pesquisador e de iniciação científica como "estratégias relevantes para desenvolver futuros pesquisadores". Chega-se à constatação de que "é preciso haver disponibilidade entre orientador e orientandos para o exercício da atividade de orientação das dissertações e teses, os meios de comunicação via internet facilitam sobremaneira".

Ao tratar da construção da tese de doutorado Rosa (2002) considerou que "o pesquisador tem que aliar o domínio teórico do seu tema, o domínio das técnicas de investigação e buscar desenvolver a criatividade e imaginação para resolver os múltiplos problemas que surgem no decorrer da investigação". Em seu modo de entender, "À medida em que se avança no processo de pesquisa, o projeto vai sendo aprimorado, clareado e principalmente reduzido nas suas pretensões".

No texto produzido por Santos (2002), encontramos considerações sobre o processo de pesquisa indicando a necessidade que tem o pesquisador de se interrogar a respeito da "importância e o alcance do objeto de estudo e qual sua ligação com o contexto sociocultural". Para essa autora "os objetos de investigação não são construídos de uma assentada, por uma espécie de ato teórico inaugural, mas paulatinamente, através de retoques sucessivos, correções, emendas, assemelha-se ao trabalho de um artesão". Nesse processo "deve-se ter um bom referencial para a construção do quadro teórico o qual é essencial para conceituar algumas categorias centrais relacionadas ao objeto de pesquisa". Caminhada similar é apresentada por Pierre (2002) que ao refletir a respeito da trajetória de uma dissertação informa: "a construção do objeto de estudo deve ser bem delimitada e apoiada em fontes bibliográficas". No decorrer desse processo "é fundamental que se escolha um tema que esteja respaldado num real interesse do pesquisador, pois uma pesquisa só tem bom termo quando há uma identificação com ela". Além desses aspectos "atividades extra-sala também auxiliam no desenvolvimento do Projeto de Pesquisa". Entretanto, destaca que "o processo de orientação é essencial na caminhada de construção da pesquisa".

No estudo de Brandão (2002) foi possível perceber que a formação pós-graduada deve ser incrementada com "estudos e elaboração de trabalhos de vários tipos: revisão de literatura, resenhas críticas de artigos e livros, relatórios e atas de pesquisa". Além disso, destaca: "as bibliotecas e nelas os periódicos nacionais e estrangeiros são indispensáveis para garantir o desenvolvimento do hábito de consulta e de atualização permanente". No entanto, os "excessos" devem ser evitados: idéias demais, combinação demasiada de autores na 
construção de uma argumentação, adjetivação e pretensão demais, o uso indiscriminado das citações. $\mathrm{O}$ uso de banco de dados e a incursão pelas áreas afins à educação são plenamente recomendados.

Machado (2002) mostrou que "poucos discursos e poucas pesquisas têm-se desenvolvido em torno do tema da orientação". Na sua concepção "escrever faz parte do instrumental de base", daí porque "toda pesquisa precisa tomar uma forma material visível, para que possa circular, ser lida, aprimorada, contrariada ou utilizada. Eis nesse ponto a proximidade da função do orientador com o desenvolvimento da autoria". Contudo, "escrever é o princípio da pesquisa, mas não é fácil". A autora preleciona: "Se queremos pesquisadores criativos, precisamos de autores, de sujeitos que tenham intimidade com as letras, e este traquejo está muito mais próximo da poética do que de qualquer outra prática".

Com a leitura do trabalho de Severino (2002) tornou-se possível esclarecer a importância de uma práxis científica, especialmente porque "no âmbito da pós-graduação essa postura é absolutamente imprescindível, pois a prática sistematizada da investigação científica encontra aí o seu lugar natural, uma vez que sua atividade específica é a própria pesquisa". Verifica-se que "A realização de uma pesquisa científica está no âmago do investimento acadêmico exigido pela pós-graduação e é o objetivo prioritário dos pós-graduandos e seus professores". Além disso, "a condução da vida do pós-graduando deve ser integralmente impregnada pela incorporação de um espírito investigativo e dedicada a uma efetiva prática de pesquisa", uma vez que "o aprendiz de pesquisador precisa desenvolver atitudes e procedimentos marcados pelo rigor, pela seriedade, pela metodicidade e pela sistematicidade, maturidade intelectual e autonomia". Para tanto o "espaço acadêmico e científico da pós-graduação deve ser, efetivamente, uma sementeira. $O$ pesquisador precisa vivenciar uma experiência problematizadora". Destaca o papel das linhas de pesquisa, o envolvimento de alunos da graduação e pós-graduação, e dos professores. De outra parte, reconhece que "as relações entre orientador e orientando, no contexto da formação pósgraduada, devem ser entendidas como um processo de construção solidária, um intercâmbio de experiências que se encontram em fases diferentes". Pondera ao dizer: "O orientador não é nem pai, nem tutor, nem advogado de defesa, nem analisa, mas também não é feitor, coronel ou coisa que o valha. Ele é um educador, estabelecendo com o seu orientando uma relação educativa, com tudo o que isso significa no plano da elaboração científica". A esse respeito, mostra que "De seu lado, o orientando deve ir conquistando progressivamente sua maturidade, segurança e autonomia para o exercício de sua criatividade. Em todas as etapas do processo, cabe-lhe tomar a iniciativa, de modo a obter a contribuição enriquecedora do orientador, a quem compete interagir com o orientando, sugerindo-lhe pistas, testando opções, esclarecendo caminhos, clareando propostas e desvelando pontos fracos".

A produção científica apresentada por Chassot (2002) relacionada à orientação virtual revela que "escrever é preciso e constitui o princípio da pesquisa", por conseguinte "No trabalho de orientação, muitas vezes, o ensinar a escrever é necessário". Segundo seu ponto de vista "a orientação através da internet" é defendida como "uma alternativa válida quando das usuais dificuldades para encontros reais", podendo esse mecanismo pedagógico servir para encurtar distâncias entre orientador e orientando. Portanto, a disponibilidade de acesso e utilização dos novos meios de comunicação facultam aos sujeitos do processo formativo diferentes alternativas ao trabalho de orientação, tais como: uso do correio eletrônico, organização de grupos de discussões para orientação, participação de diferentes orientandos, formação de um diário de bordo por meio das mensagens enviadas. Com isso, fica evidente que "Em face da expansão da rede internet se pode pensar na expansão das possibilidades de orientação virtual". 
Para Castro (2002) ao analisar o processo de orientação, considera que "cada orientador tem seu estilo pessoal de trabalho", assim como os orientandos apresentam uma "variedade de personalidades e estilos". Nesse sentido, enfatiza: "Se o aluno não tem a disposição, gosto ou as qualificações para alguma coisa além de coletar dados, julgamos então que não é talhado para a pós-graduação, destinada à elite científica da sociedade". Denuncia um conjunto de situações que marcam essa caminhada em torno da pesquisa orientada: ambição excessiva, tratados definitivos, história da humanidade como tema, mau disposição do tempo, excesso de dados e escassez de análise, ofensas à língua pátria, orientador como guia espiritual e consultor sentimental. Ressalta que "Seguramente, o aspecto mais cansativo e desalentador de orientar uma tese resulta da incapacidade e inexperiência do aluno em questões de redação". Mesmo com todas essas considerações o autor conclui que "O orientador deve permitir e estimular divergências de opinião entre o orientando e ele próprio", posto que "os orientadores variam em seus estilos", como também os pós-graduandos que se encontram sob sua condução.

Para Saviani (2002) "O ponto nodal do sistema de pós-graduação reside na questão da orientação". Tal opção se justifica pelo fato de se ter a formação do pesquisador como principal objetivo, razão pela qual a pesquisa deve servir de eixo estruturante da organização desse sistema formativo. Porém, diz: "Penso ser necessário conferir uma atenção e cuidado especiais ao problema da orientação", o qual implica reconhecer a "proposta de iniciativa do aluno", como também "sugerir temas de investigação". Isto fez com que o autor passasse a dar credibilidade ao trabalho de "orientação coletiva" combinando-a com "atendimento individual sistemático". Tais procedimentos permitem a consolidação dos "grupos de pesquisa", a sistematização da "produção das pesquisas" conduzidas pelos professores e o envolvimento dos alunos na "produção de conhecimentos".

Bianchetti (2002) discutiu o desafio de escrever dissertações e teses mostrando que essa atividade acadêmica "é sempre um desafio". No que concerne ao vínculo orientador e orientando, considera que "este processo deveria receber mais atenção e sobre ele serem feitas mais pesquisas...". Além disso, "pouco se encontra escrito-pesquisado sobre a função orientadora, o que a envolve e os personagens que a concretizam". Por outro lado, percebe o quanto "a partir da metade da década de 1990, a preocupação com o processo de orientar dissetações/teses passou a receber uma atenção mais particularizada, embora ainda não se constituindo num campo de pesquisa". Em face do tempo que rege a sistemática de avaliação adotada pelas agências de fomento, percebe que "se muito tempo for despendido freqüentando aulas, fazendo disciplinas ou coletando dados, fatalmente faltará tempo para análise, a escrita e revisão", daí porque vê a necessidade de "conciliar o tempo do orientador, do pós-graduando e o tempo institucional”. Essa situação é agravada ainda mais quando se nota que "os alunos que vêm ingressando na pós-graduação são cada vez mais novos e com menos experiências em termos de ensino e, principalmente, pesquisa, aspecto que demanda mais tempo para sua formação, e não a diminuição".

O estudo realizado por Marques (2002) também discutiu a pesquisa na pós-graduação mostrando a centralidade da "formação da pesquisa autônoma" nos níveis de mestrado e doutorado. Portanto, fica evidente que "se a pesquisa se concretiza na urdidura de texto de autoria própria, então se constitui o escrever em princípio da pesquisa". Dentro desse horizonte intelectual "orientar significa ajudar o orientando a descobrir o que quer investigar, delimitando seu tema/hipótese de trabalho traduzida em título conciso, capaz de se decompor em capítulos e estes em itens distintos". Do ponto de vista da competência do orientador, cabe-lhe: ler com atenção o que o orientando vem escrevendo, não se imiscuir no texto alheio nem sujeitá-lo a objetivos que não os do orientando, acertar com o aluno 
determinados prazos e cobrá-los, levar o pesquisador iniciante a descobrir o que realmente pretende, sugerir conversas e leituras apropriadas, o uso de técnicas de trabalho. Verificouse que "o orientador de pesquisa é alguém que acompanha os passos de seu orientando, um leitor, não um alguém que escreve-pesquise em lugar do aprendiz, nem alguém que o convoque para trabalho alheio".

Os escritos de Haguette (2002) revelaram que no processo de produção do conhecimento "o domínio dos meandros metodológicos exerce uma influência primordial sobre a forma como o orientador se conduz na relação com o orientando". Durante o desenvolvimento da atividade de orientação "o aluno fica à mercê da competência ou incompetência do orientador". Este fato torna explícita a constatação segundo a qual "a capacidade de orientação e formação de pesquisadores juniores, portanto, depende diretamente do conhecimento teórico-prático dos seus mentores". Logo, "o programa de mestrado não forma bons pesquisadores porque seu próprio staf não foi bem formado nem adquiriu competência posterior através da prática da pesquisa. Mas felizmente existem as honrosas exceções". Propõe "alguns mandamentos do bom orientador": não discutir verbalmente o problema de pesquisa com o aluno exigindo que ele se expresse por escrito; não fazer imposição de problemática ao aluno; não exigir inclusão de autores prestigiados pelos orientadores a não ser que sejam imprescindíveis; respeitar a lógica do aluno; levar o orientando até onde ele pode ir, respeitando os limites de qualidade; possibilitar ao orientando conhecer diferentes alternativas teóricas sobre seu objeto de estudo; ajudar os alunos a escolher as categorias analíticas; exigir metodologia rigorosa; apontar, corrigir e solicitar que o aluno encaminhe para correção, as falhas de estilo e escrita; transmitir confiança e otimismo ao orientando; falar a verdade ao aluno quanto aos defeitos do trabalho; elogiar, sempre que merecido, o desempenho do orientando; manter um relacionamento profissional e amigável; elaborar cronograma de atividades; fazer críticas e reparos, mas indicar caminhos e soluções; não aproveitar a cátedra para fazer catequese, doutrinação ideológica ou militância política; não fazer patrulhamento ideológico dentro da academia; não fazer concessões à mediocridade; respeitar os princípios da ética universitária; não levar o orientando à defesa sem a certeza de que a banca aprovou o trabalho; evitar a presença de desafetos nas bancas; o orientando tem o direito de ser atendido periódica e delicadamente pelo orientador e de ter seus textos lidos, anotados, e devolvidos para posterior discussão.

A pesquisa de Zilbermann (2002) apropriou-se da orientação como aventura compartilhada. Em função disso, percebeu que "a redação da dissertação e/ou tese constitui um esforço individual. Todavia, não é solitário porque interfere, em sua realização, um segundo sujeito - o orientador". A produção científica assim conduzida permite ao orientando “...contar com o suporte de um pesquisador que não apenas já passou por isso, como conhece sua área, podendo ajudá-lo na construção desse conhecimento específico".

Nota-se que a produção de conhecimento sob a forma de dissertação ou tese requer o desenvolvimento de um trabalho em parceria, a qual envolve, no mínimo, a relação orientador-orientando, mas também requer da parte dos Programas existentes, o cultivo da diversificação dos dispositivos pedagógicos utilizados na formação acadêmica. Assim, a pesquisa precisa ser encarada como dimensão vertebral e em torno dela devem ser articuladas atividades curriculares consubstanciadas no corpo das disciplinas e das tarefas sistematicamente exigidas.

O ambiente institucional da pós-graduação deve ser propício ao estímulo à investigação, daí porque as finalidades das atividades acadêmicas dos discentes precisa se conectar com a sistematização e a produção de conhecimento novo, o que lhes exigirá o imprescindível exercício da escrita e da autoria, com o auxílio de seu guia intelectual, o orientador. 


\section{Considerações Finais}

No decorrer do estudo de caráter teórico, tornou-se possível formular um banco de dados correspondente a alguns dos trabalhos que assumem a temática da orientação das dissertações e teses como objeto de investigação, verificando-se especificamente que os autores têm localizações espaciais e institucionais diferenciadas, sendo limitados os números dos trabalhos existentes e diversificados os veículos escolhidos pelos seus autores a fim de publicá-los.

A radiografia dessas produções acadêmicas igualmente permitiu constatar a participação dos autores segundo o gênero, com a primazia de um ou outro sexo quando se considera a Região, e o Veículo de circulação, assim como os eixos analíticos que adotei para consolidar os trabalhos examinados.

Os livros, capítulos de livros, periódicos e Reuniões Anuais revelaram-se fontes históricas fundamentais que guardam primorosas informações relacionadas ao tema da pósgraduação na sua particularidade relacionada ao processo de orientação das dissertações e teses. O mapeamento dessa produção exigiu o uso da internet, assim como a ida a livrarias para consultar e adquirir obras correlatas ao tema posto em evidência neste estudo.

A partir da aquisição dos textos, leituras e análises foram desenvolvidas tendo por referência sua decomposição segundo as dimensões: Autor, Título do Trabalho, Finalidade da Pesquisa, Questões investigativas, Metodologia empregada, Fontes Históricas utilizadas, Período Histórico abrangido e os Resultados atingidos, principalmente aqueles que indicavam aspectos concernentes à atividade acadêmica de orientação das pesquisas científicas no contexto da Pós-Graduação.

Esse levantamento bibliográfico permitiu apreender a incidência das produções acadêmicas não apenas quanto ao número de autores e sua correspondente distribuição regional, institucional e por gênero, como também a movimentação desses trabalhos e o crescimento no número dos textos existentes segundo a temporalidade de seu aparecimento público.

As informações analisadas permitiram concluir que homens e mulheres participam em proporções desiguais na composição da autoria dos trabalhos científicos; as instituições que os absorvem são predominantemente públicas com sede no território da Região Sudeste; os autores envolvidos adotam os Capítulos de Livros como veículo predominante, mas assumem formatos diversos na propagação dos textos ao longo da série histórica.

Percebeu-se que quando se tratava de analisar as Políticas de Pós-Graduação, houve a presença marcante das mulheres do Sul, utilizando-se do GT-11 ANPEd como principal referência para publicação. No entanto, as pesquisas dirigidas para a Avaliação da PósGraduação, evidenciaram outra tendência na qual a Região Sudeste alcançou o ponto mais elevado, os homens detiveram a maioria e o Veículo de publicação ficou com a supremacia da RBE. Já aqueles textos cujos autores discutiram o Processo de Orientação das Dissertações e Teses, o Sul voltou a se destacar como espaço territorial de maior produtividade, o sexo feminino teve maior expressividade e os Capítulos de Livros foram eleitos o meio de divulgação dos resultados daqueles estudos desenvolvidos pelos intelectuais.

Notou-se que no universo acadêmico da Pós-Graduação, cresce o interesse dos pesquisadores pelo campo do Processo de Orientação de Dissertações e Teses. Contudo, essa movimentação intelectual em torno desse objeto constitui fenômeno recente que desafia o exercício da curiosidade da comunidade científica, assim como tem provocado o aumento no volume de escritos a respeito do tema. 
As argüições formuladas pelos autores dos trabalhos que deram substrato a essa pesquisa, demonstraram o quanto a Pós-Graduação e, nessa seara, a relação pedagógica estabelecida entre orientador e orientando, abriga fenômenos educativos pouco explorados. O que demanda a realização de estudos mais freqüentes, não apenas pelo protagonismo isolado de cada pesquisador-docente dos Programas, mas na articulação possível entre eles e seus orientandos, assim como na parceria interinstitucional com Núcleos e Grupos de Pesquisa existentes no País ou fora dele.

Verificou-se a existência de escolhas metodológicas diversificadas nos escritos dos autores. Isto resulta da variação nos temas priorizados, assim como nos problemas de pesquisa e nas finalidades pretendidas com os estudos. No entanto, percebeu-se que em determinados trabalhos a metodologia não teve nenhuma referência.

Persiste um número elevado de práticas investigativas que se apóiam nos documentos oficiais, porém, já há pesquisas que têm seu indício em outros tipos documentais. Aumenta a tendência para o uso de informações e conhecimentos situados na base de dados das agências de fomento à pesquisa e dos Programas de Pós-Graduação, assim como a consulta a periódicos, relatórios, dissertações e teses disponíveis ao acesso nos arquivos eletrônicos que podem ser consultados via internet.

Foram identificados também grupos de trabalhos que assumiram como linha metodológica o recurso ao enlace da pesquisa bibliográfica com o relato de experiência, tendo como sujeitos informantes os orientadores, coordenadores de Programas de Pós-Graduação, orientando e a análise do fenômeno da orientação das dissertações e teses numa perspectiva da autoformação vivida pelos autores dos textos consultados. Além disso, cabe destacar que o uso das narrativas ganhou representatividade entre as escolhas metodológicas assumidas nesses escritos acadêmicos.

Percebeu-se, portanto, que as opções por determinados tipos de fontes para subsidiar a produção da verdade histórico-científica, requer sincronia entre a temática escolhida, as opções teórico-valorativas dos pesquisadores, os problemas que fustigam sua curiosidade, as finalidades das investigações e as tecnologias metodológicas adotadas. Com base nessa relação as fontes históricas serão julgadas (im)pertinentes na captura dos acontecimentos e fatos por meio dos vestígios que nutrem a composição dos textos escritos.

O tempo de longa duração constituiu a segunda opção eleita pelos autores, superando a proporção daqueles que preferiram a análise de superfície. Porém, a duração cíclica, ou seja, a análise conjuntural predomina nos escritos dos cientistas brasileiros.

Assim, pode-se dizer que o tempo histórico resulta do processo de construção do objeto escolhido para estudo, não se restringindo a uma cronologia estática. Contribui para sua composição os temas escolhidos, os vestígios relacionados aos acontecimentos e fatos históricos, o momento de efetiva realização do fenômeno. Nota-se, portanto, a importância da cronologia para tentar apreender o movimento do objeto, sua produção e efeitos nas instituições e nos sujeitos alcançados por suas verberações.

Os Programas de Pós-Graduação precisam atribuir maior visibilidade ao processo de orientação das dissertações e teses, pois esse momento pedagógico tem merecido pouca atenção institucional, como também escapa das opções temáticas investigativas de grande parte dos pesquisadores brasileiros.

\section{Referências}

ALMEDIDA JÚNIOR, A.; SUCUPIRA, N. et. al. Parecer CFE nº 977/65, aprovado em 3 dez. 1965. Rio de Janeiro. Revista Brasileira de Educação. Rio de Janeiro: Revista Brasileira de Educação. set/out/nov/dez 2005 n 30. Especial sobre os 40 anos da pósgraduação em educação. p.162-173 
BARRETO, F. C. S. O futuro da pós-graduação brasileira. São Paulo: Instituto de Estudos Avançados - IEA. 2006. http://www.iea.usp.br/observatorios/educacao

BIANCHETTI, L. O desafio de escrever dissertações/teses: como incrementar a quantidade e manter a qualidade com menos tempo e menos recursos? In. BIANCHETTI, L.; MACHADO, A. M. N. (Orgs.) A bússola do escrever: desafios e estratégias na orientação de teses e dissertações. São Paulo: Cortez, 2002. p. 165-185

BIANCHETTI, L.; MACHADO, A. M. N. Orientação de teses e dissertações: individual e/ou coletiva? Contextos e transformações nos 40 anos da pós-graduação strictu sensu em educação no Brasil. 29a Reunião Anual da Associação de Pesquisa e Pós-Graduação em Educação - ANPEd. Caxambú-MG. GT-11 Política de Educação Superior. 15 a 18 de outubro de 2006. http://www.anped11.uerj.br Acesso em 27/07/2007

BIANCHETTI, L.; CARTANA, C. F.; MARTINS, Letícia Aparecida. Orientação/escrita de dissertações e teses em questão: produção científica e estratégias de orientadores de programas de pós-graduação em educação. Anais da $58^{a}$ Reunião Anual da SBPC Florianópolis, SC - Julho/2006.

BRANDÃO, Z. Pesquisa em educação: conversas com pós-graduandos. Rio de Janeiro: Ed. PUC-Rio; São Paulo: Loyola, 2002.

CASTRO, C. M. Memórias de um orientador de tese: um autor relê sua obra depois de um quarto de século. In. BIANCHETTI, L.; MACHADO, A. M. N. (Orgs.) A bússola do escrever: desafios e estratégias na orientação de teses e dissertações. São Paulo: Cortez, 2002. p. $109-134$

CHASSOT, A. I. Orientação virtual: uma nova realidade. In. BIANCHETTI, Lucídio; MACHADO, A. M. N. (Orgs.) A bússola do escrever: desafios e estratégias na orientação de teses e dissertações. São Paulo: Cortez, 2002. p. 89-108

FÁVERO, M. L. A. GT Política de Educação Superior da ANPEd: origem, desenvolvimento e produção. Rio de Janeiro: Revista Brasileira de Educação. set/out/nov/dez 2002 n $^{\circ} 21$. p.115-126

FRANCO, M. E. D. P.; MOROSINI, Marília Costa. Pós-Graduação brasileira e política de diversificação. 24a Reunião Anual da Associação Nacional de Pesquisa e PósGraduação em Educação - ANPEd. Caxambú-MG, GT-11Polítida de Educação Superior. http://www.anped11.ueri.br Acesso em 27/07/2007

GATTI, B. A.; ANDRÉ, M.; FÁVERO, O.; CANDAU, V. M. F. O modelo de avaliação da CAPES. Rio de Janeiro: Revista Brasileira de Educação. jan/fev/mar/abr. no 22. 2003. p.137-144

GATTI, B. A. Reflexão sobre os desafios da pós-graduação: novas perspectivas sociais, conhecimento e poder. Rio de Janeiro: Revista Brasileira de Educação. set/out/nov/dez $2001 \mathrm{n}^{\mathrm{o}}$ 18. p.108-116

HAGUETTE, T. M. F. Universidade: nos bastidores da produção do conhecimento. In. BIANCHETTI, L.; MACHADO, A. M. N. (Orgs.) A bússola do escrever: desafios e estratégias na orientação de teses e dissertações. São Paulo: Cortez, 2002. p. 371-382

LEAL, D. R. A construção da tese de doutorado e a questão do método. In: MATOS, K. S. L. e VASCONCELOS, J. G. (Orgs.). Registros de pesquisa em educação. Fortaleza: LCR, UFC, 2002. p. 70-79 
LEITE FILHO, G. A. e MARTINS, G. A. Relação orientador-orientando e suas influências na elaboração de teses e dissertações. Minas Gerais: RAE, vol. 46 - Edição Especial, 2006. p. 99-109

LÜDKE, M. Influências cruzadas na constituição e na expansão do sistema de pósgraduação stricto sensu em educação no Brasil. Rio de Janeiro: Revista Brasileira de Educação. set/out/nov/dez. n ${ }^{\circ}$ 30. Especial sobre os 40 anos da pós-graduação em educação. 2005. p.117-123

MACHADO, A. M. N. A relação entre a autoria e a orientação no processo de elaboração de teses e dissertações. In. BIANCHETTI, Lucídio; MACHADO, Ana M. N. (Orgs.) A bússola do escrever: desafios e estratégias na orientação de teses e dissertações. São Paulo: Cortez, 2002. p. 45-66

MACHADO, A. M. N. Caminhos ou (des)caminhos da pós-graduação strictu sensu em educação no Brasil. 28 ${ }^{a}$ Reunião Anual da Associação Nacional de Pesquisa e Pósgraduação em Educação - ANPED. Caxambú-MG. GT-11 Política de Educação Superior. http://www.anped11.uerj.br Acesso em 27/07/2007

MACHADO, A. M. N.; LEHMKUHL, A. C. Obstáculos no processo de orientação de teses e dissertações: análise das manifestações de orientadores experientes. $27^{\mathrm{a}}$ Reunião Anual da Associação Nacional de Pesquisa e Pós-Graduação em Educação - ANPEd. Caxambú-MG, 2004. http://www.anped11.uerj.br Acesso em 27/07/2007

MARQUES, M. O. A orientação das pesquisas nos programas de pós-graduação. In. BIANCHETTI, L.; MACHADO, A. M. N. (Orgs.) A bússola do escrever: desafios e estratégias na orientação de teses e dissertações. São Paulo: Cortez, 2002. p. 227-234

MATOS, K. S. L. Percursos de pesquisa: rompendo com omonoteísmo metodológico. In: MATOS, K. S. L. e VASCONCELOS, J. G. (Orgs.). Registros de pesquisa em educação. Fortaleza: LCR, UFC, 2002. p. 11-22

MAZZILLI, S. O papel da orientação na formação de pesquisadores em educação. $28^{\mathrm{a}}$ ? Reunião Anual da Associação Nacional de Pesquisa e Pós-Graduação em Educação ANPEd. Caxambú-MG. GT-04 Didática, 2007/8?.

PIERRE, C. M. M. Trajetória de uma dissertação. In: MATOS, K. S. L. e VASCONCELOS, J. G. (Orgs.). Registros de pesquisa em educação. Fortaleza: LCR, UFC, 2002. p.99-105

PRESTES, E. M. T.. Globalização, políticas de pós-graduação e desigualdade regional. $20^{a}$ Reunião Anual da Associação Nacional de Pesquisa e Pós-Graduação em Educação ANPEd. Caxambú-MG. GT-11 Política de Educação Superior. http://www.anped11.uerj.br Acesso em 27/07/2007

RAMALHO, B. L. 40 anos de pós-graduação em educação no Brasil: produção do conhecimento, poderes e práticas. Rio de Janeiro: Revista Brasileira de Educação. jan/abr. v. 11 - no 31. Especial sobre os 40 anos da pós-graduação em educação. 2006. p. 183-185

RAMALHO, B. L; MADEIRA, V. P. C. A pós-graduação em educação no Norte e Nordeste: desafios, avanços e perspectivas. Rio de Janeiro: Revista Brasileira de Educação. set/out/nov/dez no 30, 2005. p. 70-81

ROMÊO, J. R. M.; ROMÊO, C. I. M.; JORGE, V. L. Estudos de pós-graduação no Brasil. UNESCO: IESALC - IES/2004/ED/PI/19. 2004 
SANTOS, M. I. D. A. Uma retrospectiva sobre o percurso do investigador no processo de pesquisa. In: MATOS, K. S. L. e VASCONCELOS, J. G. (Orgs.). Registros de pesquisa em educação. Fortaleza: LCR, UFC, 2002. p.80-90

SAVIANI, D. A pós-graduação em educação no Brasil: pensando o problema da orientação. In. BIANCHETTI, Lucídio; MACHADO, Ana M. N. (Orgs.) A bússola do escrever: desafios e estratégias na orientação de teses e dissertações. São Paulo: Cortez, 2002. p. $135-163$

A pós-graduação em educação no Brasil: trajetória, situação atual e perspectivas. Revista Diálogo Educacional. V. 1 -n. 1 - p.1-95 - jan/jun. 2000. p. 1-19

SEVERINO, A. J. Pós-Graduação e pesquisa: o processo de produção e de sistematização do conhecimento no campo educacional. In. BIANCHETTI, Lucídio; MACHADO, Ana M. N. (Orgs.) A bússola do escrever: desafios e estratégias na orientação de teses e dissertações. São Paulo: Cortez, 2002. p.67-88

ZILBERMANN, R. Orientação: a aventura compartilhada. In. BIANCHETTI, Lucídio;

Notas:

${ }^{1}$ Universidade Federal do Pará; Instituto de Ciências da Educação; Faculdade de Educação; Programa de Pós-Graduação em Educação - Email: paulosac@ufpa.br

${ }^{2}$ A noção de tempo histórico aqui indicada segue a classificação da História segundo seus Tempos, conforme definições atribuídas pela Escola dos Annales: o nível da Longa Duração analisa a estrutura em profundidade; o nível da Duração Cíclica atém-se ao estudo da conjuntura e o nível do Tempo Curto quando o pesquisador se dedica ao exame do acontecimento imediato, prendendo-se no âmbito da superfície. Cf. BOUDÉ, Guy; MARTIN, Hervé. As escolas históricas. Portugal: Europa-américa, 1983.

Recebido em janeiro/2012

Aprovado em junho/2012 